\title{
Impact of genotype on fatty acid profile, oil content and nutritional value of the sweet fruits of Acrocomia aculeata
}

\author{
Rosemar Antoniassi ${ }^{1}$, Sidinea Cordeiro de Freitas ${ }^{2}$, Tania dos Santos Silva ${ }^{3}$, \\ Manuela Cristina Pessanha de Araujo Santiago ${ }^{4}$, Allan Eduardo Wilhelm ${ }^{5}$, Nilton Tadeu Vilela Junqueira ${ }^{6}$
}

\begin{abstract}
Macauba (Acrocomia aculeata) has mainly been evaluated as an oil source focused on biodiesel production. Furthermore, the fruit mesocarp and kernel are edible, and candies, jelly, sweet alcoholic liquor and ice cream are also produced from the mesocarp. Despite its consumption, there is still a lack of information on the nutritional composition of macauba. Selected macauba genotypes producing fruits with a sweet mesocarp were evaluated regarding the fruit characteristics, proximate composition, oil content and fatty acid profile. The mesocarp total sugar (fructose and glucose) content ranged from 4.5 to $9.6 \mathrm{~g} / 100 \mathrm{~g}$, total dietary fiber varied from 6.8 to $9.3 \mathrm{~g} / 100 \mathrm{~g}$, while protein content was up to $2.2 \mathrm{~g} / 100 \mathrm{~g}$ (wet basis). There was a significant difference among genotypes for fruit characteristics, pulp oil content $(7-29 \mathrm{~g} / 100 \mathrm{~g}$ wet basis), and fatty acids from the mesocarp such as C18:1 (36-63\%), C18:2 (7-35\%) and C18:3 (0.8-7\%)(p<0.05), and one of the evaluated genotypes may contribute to daily intake of linoleic and linolenic acids. The carotenes in the mesocarp oil ranged from $30-240 \mathrm{mg} / \mathrm{kg}$. Lauric acid was the main fatty acid in the kernel oil. The differences observed depended on the genetic diversity and point out the nutritional value and different applications for macauba mesocarps.
\end{abstract}

Index terms: Macauba; total dietary fiber, sugars; mesocarp; kernel.

\section{Impacto do genótipo no perfil de ácidos graxos, no teor de óleo e no valor nutricional dos frutos doces de Acrocomia aculeata}

Corresponding author: rosemar.antoniassi@embrapa.br

Received: July 07, 2020 Accepted: August 11, 2020

Copyright: All the contents of this journal, except where otherwise noted, is licensed under a Creative Commons Attribution License.

(cc) $\mathbf{E Y}$
Resumo - A macaúba (Acrocomia aculeata) tem sido avaliada como fonte de óleo focada principalmente para a produção de biodiesel. Além disso, o mesocarpo e a amêndoa são comestíveis, e produtos como doces, geleia, licor e sorvete têm sido produzidos a partir do mesocarpo. Apesar de seu consumo, ainda há pouca informação sobre a composição nutricional da macaúba. Os genótipos selecionados de macaúba apresentando frutos com mesocarpo doce foram avaliados quanto às características do fruto, composição nutricional, teor de óleo e perfil de ácidos graxos. O mesocarpo apresentou açúcares totais (frutose e glicose) variando de 4,5 a 9,6 g/100 g, fibra alimentar total variando de 6,8 a 9,3 g/100 g, enquanto o teor de proteína foi de até $2,2 \mathrm{~g} / 100 \mathrm{~g}$ (base úmida). Houve diferença significativa entre os genótipos quanto às características do fruto, teor de óleo de polpa (7-29 g/100 g de base úmida), ácidos graxos do mesocarpo, como C18:1 (36-63\%), C18:2 (7-35\%) e C18:3 $(0,8-7 \%)(\mathrm{p}<0,05)$. Os carotenos de óleo do mesocarpo variaram de 30 a $240 \mathrm{mg} / \mathrm{kg}$. O ácido láurico foi o principal ácido graxo da amêndoa. As diferenças observadas mostram o impacto da variação genética entre os genótipos avaliados e mostram o valor nutricional e as diferentes aplicações para o mesocarpo da macaúba.

Termos para indexação: Macaúba; fibra alimentar, açúcares; mesocarpo; amêndoa.

${ }^{1} \mathrm{PhD}$, Researcher at Embrapa Agroindústria de Alimentos, Rio de Janeiro- RJ, Brazil. Email: rosemar.antoniassi@embrapa.br(ORCID 0000-00020795-9877)

${ }^{2} \mathrm{PhD}$, Researcher at Embrapa Agroindústria de Alimentos, Rio de Janeiro- RJ, Brazil. Email: sidinea.freitas@embrapa.br ${ }^{(0 \mathrm{RCID} 0000-0002-0398-}$ 1268)

${ }^{3}$ M.Sc., Analyst at Embrapa Agroindústria de Alimentos, Rio de Janeiro- RJ, Brazil. E-mail: tania.silva@embrapa.br (ORCID 0000-0002-4031-1394); ${ }^{4} \mathrm{PhD}$, Analyst at Embrapa Agroindústria de Alimentos, Rio de Janeiro- RJ, Brazil. E-mail: manuela.santiago@embrapa.br ${ }^{(0 \mathrm{RCID} 0000-0003-}$ 4459-2258)

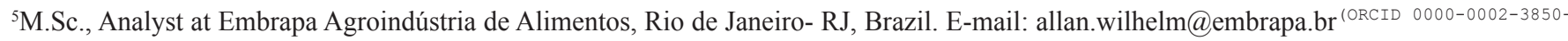
8681)

${ }^{6} \mathrm{PhD}$, Researcher at Embrapa Cerrados, Planaltina-DF, Brazil. Email: nilton.junqueira@embrapa.br (ORCID 0000-0001-9814-7104) 


\section{Introduction}

Acrocomia aculeata (Jacq.) Lodd. ex Mart. (family Arecaceae) is a spiny, single-stemmed palm which grows up to $16 \mathrm{~m}$ in height, and extends from southern Mexico through Central America and the Antilles to northern Argentina. The largest concentrations are found in Paraguay and in the Brazilian States of Minas Gerais, Goias, Mato Grasso and Mato Grosso do Sul, where massive stands are mostly present in pastures as the dominant tree, but also in pastures with shrub vegetation and in forests (SCARIOT et al., 1995). The fruits are spherical or slightly flattened in the shape of a globular drupe, with a diameter ranging from 2.5 to $5.0 \mathrm{~cm}$. The epicarp breaks easily when mature. The mesocarp is edible, fibrous and mucilaginous, sweet in taste, rich in oil and yellow. The endocarp is strongly adhered to the pulp (mesocarp) and contains a white kernel (LORENZI et al., 2010).

Lorenzi and Negrelle (2006) reported several applications and uses for macauba including the trunk as wood, the leaves for animal fodder, the stipe to obtain palm heart and sap used as food and drink, respectively. Fruits are eaten fresh or used for oil extraction. The pulp is used to prepare sweetened alcoholic liquor and ice cream, and the kernel serves as food. Several applications and recipes of Cerrado (Brazilian savannah) fruits including macauca mesocarp and kernel were presented by Almeida (1998).

The potencial of macauba as an oil source has been evaluated focusing on biodiesel production (BERGMANN et al., 2013; COLOMBO et al., 2018; CONCEIÇÃO et al., 2013,a, b, 2015b; FERRARI and AZEVEDO FILHO, 2012; LOPES and STEIDLE NETO, 2011). Therefore the oil content and the fatty acid profile of both the mesocarp and kernel oils and fruit characteristics have been more studied than its nutritional value (CONCEIÇÃO et al., 2013,a,b, 2015b; HIANE et al., 2005; VIANNA et al., 2017). Information related to nutritional composition is scarce, and a large variation has been observed for the protein content of the mesocarp ranging from 1.5 to 6.7\% (RAMOS et al., 2008; COIMBRA and JORGE, 2011), while total dietary fiber has been presented for some macauba genotypes without evaluating the sugar content. Regarding the presence of sugars, Mooz et al. (2012) reported $3.99^{\circ}$ Brix for the mesocarp, while Ramos et al. (2008) cited glucose as the main sugar in the macauba mesocarp $(9.5 \mathrm{~g} / 100 \mathrm{~g})$. Additionally, bioactive compounds of the mesocarp such as ascorbic acid were measured, ranging from 14.7 to $15.4 \mathrm{mg} / 100 \mathrm{~g}$ (MOOZ et al., 2012; LESCANO et al. 2015), carotenoids $(300 \mu \mathrm{g} / \mathrm{g}$ ) and tocopherols $(213 \mathrm{mg} / \mathrm{kg})$ for dried pulp by Coimbra and Jorge (2011), and calcium $(67 \mathrm{mg} / 100 \mathrm{~g})$ and zinc $(0.7$ $\mathrm{mg} / 100 \mathrm{~g}$ ) for wet pulp (TACO, 2011).
The selection of $A$. aculeata genotypes for oil production was carried out by Embrapa Cerrados (Brazilian Agricultural Research Corporation) by evaluating massive palm stands covering four Brazilian states in the Cerrado region (CONCEIÇÃO et al., 2013a,b, CONCEIÇÃO et al., 2015a,b). Meanwhile, the communities of these areas reported their traditional knowledge, and according to Junqueira (2020) the first inhabitants of Cerrado region used macauba oil for lighting, and the pulp was consumed at breakfast, although they preferred the sweet fruits with low oil content because the oily fruits may cause diarrhea. The kernel was used to feed domestic animals such as pigs, chicken and cows. The sweet macauba fruits were also consumed by the caninde macaw (Ara glaucogularis, family Psittacidae), and their presence was used for identifying these genotypes.

In this work, three sweet macauba genotypes were selected based on the traditional knowledge of the local population who usually produce candies, ice cream, jelly and other products with the mesocarp of these fruits. A comparison of sweet macauba genotypes was carried out regarding fruit characteristics, proximate composition and the sugars profile of the mesocarp and fatty acid composition of the mesocarp and kernel oils.

\section{Material and Methods}

\section{Material}

The sweet genotypes of Acrocomia aculeata were codified as Mac 1, Mac 2 and Mac 3. The Mac1 genotype was selected from a massive stand of $A$. aculeata in the city of Formosa, Goias State, Brazil at altitude of 858 $\mathrm{m}$ and at the geographic coordinates of $15^{\circ} 54^{\prime} 25.72^{\prime \prime} \mathrm{S}$ and $47^{\circ} 21^{\prime} 47.75^{\prime} \mathrm{W}$. The Mac 2 genotype was found at the geographic coordinates of $15^{\circ} 54^{\prime} 22.86^{\prime \prime} \mathrm{S}$ and $47^{\circ} 22^{\prime} 40.00^{\prime \prime} \mathrm{W}$ in the Rural Center Jardim 2, Federal District State, Brazil at altitude of $854 \mathrm{~m}$, and the Mac 3 genotype was selected from a massive stand at altitude of $877 \mathrm{~m}$ and at the coordinates of $15^{\circ} 53^{\prime} 51.96^{\prime \prime} \mathrm{S}$ and $47^{\circ} 24^{\prime} 05.77^{\prime}$ 'W, in the Rural Center Buriti Vermelho, Federal District State, Brazil.

The collection of the ripe fruits was carried out using some nets which were placed around the trunk to catch falling fruits and the collection time was controlled to avoid fruit damage.

\section{Fruit Characteristics}

Fruits of three selected genotypes were collected from mature bunches, and kept frozen until analysis. The fruits (4 or 5) and their parts were separated and weighed (wet basis). The epicarp was removed, the mesocarp of each fruit was cut and lyophilized, and the woody

*JUNQUEIRA, N.T.V. Personal communication, 2020. 
endocarp was broken. The kernel of each fruit was then dried in an air oven $\left(60^{\circ} \mathrm{C}\right.$ for six hours). Oil from the mesocarp and kernels from each fruit was extracted by a Soxhlet apparatus (petroleum ether $30-60^{\circ} \mathrm{C}$ ) for 16 hours. The epicarp, endocarp, kernel, and mesocarp (pulp) contents related to fruit weight were evaluated on a wet basis. The kernel and pulp oil contents were reported as wet (WB) and dry basis (DM). The kernel and pulp oil yields per fruit were calculated as wet basis, and the total oil yield per fruit was the sum of both.

The pulp oil was dissolved in hexane and the carotene content was estimated by spectrophotometric analysis according to Davies (1976). It was possible to measure the carotene content for each fruit for the Mac 1 and Mac 3 samples, however the oil for the Mac 2 sample was sampled from different fruits and the analysis was carried out in duplicate.

\section{Fatty acid composition}

The fatty acid profile analyses of the mesocarp and kernel oil samples were analyzed separately for each fruit. The methyl esters were prepared according to Hartman and Lago (1973) and analyzed by gas chromatography on Agilent 7890 equipment equipped with a fused silica capillary column covered with a cyanopropylsiloxane film $(60 \mathrm{~m} \times 0.32 \mathrm{~mm} \times 0.25 \mu \mathrm{m})$ and the temperature was programmed as follows: initial temperature of $100^{\circ} \mathrm{C}$ for three min; from 100 to $150^{\circ} \mathrm{C}$ with an increase of $50^{\circ} \mathrm{C} /$ min; from 150 to $180^{\circ} \mathrm{C}$ with an increase of $1^{\circ} \mathrm{C} / \mathrm{min} ; 180$ to $200^{\circ} \mathrm{C}$ with an increase of $25^{\circ} \mathrm{C} / \mathrm{min}$, and at the final temperature of $200^{\circ} \mathrm{C}$ for $10 \mathrm{~min}$. The sample $(1 \mu \mathrm{L}$ of a $2 \% \mathrm{w} / \mathrm{v}$ ) was injected into an injector heated to $250^{\circ} \mathrm{C}$ and operated in split mode (1:50). A flame ionization detector kept at $280^{\circ} \mathrm{C}$ was used for signal collection. Identification was performed by comparing the retention times to NU-CHEK Prep, Inc. (Elysian, MN) standards and quantification was performed by internal normalization. The iodine and saponification indexes were calculated based on the fatty acid composition.

\section{Proximate composition and sugar analysis}

The pulp was removed from 10 fruits and homogenized, and the analysis was conducted in duplicate. The proximate analyses were performed according to AOAC Official methods (AOAC, 2005). The moisture was measured until constant weight in an oven at $105^{\circ} \mathrm{C}$, the ash content was conducted by calcination at $550^{\circ} \mathrm{C}$, the oil content was carried out by acid hydrolysis followed by ethyl ether and petroleum ether extraction, and total dietary fiber was determined by the enzymatic-gravimetric method (AOAC 991.43). The protein content was calculated based on nitrogen content determined by the Kjeldahl method and using the factor of 5.75 as reported for vegetable products by Brazilian nutritional labeling regulation (BRASIL, 2003).
The glucose, fructose and sucrose concentrations in the wet pulp were determined by high-performance liquid chromatography (HPLC) with a refractive index detector. The sugars were extracted with ultrapure water and acetonitrile in an ultrasonic bath for $20 \mathrm{~min}$ and the extract was filtered. The HPLC analysis was performed using a column Zorbax ${ }^{\mathrm{TM}}$ Carbohydrate $(30 \mathrm{~cm} \times 4.6$ $\mathrm{mm} \times 5 \mu \mathrm{m}$ ), and a flow rate of $1.0 \mathrm{~mL} \cdot \mathrm{min}^{-1}$ of a mobile phase of acetonitrile:water $(75: 25 \mathrm{v} / \mathrm{v})$. The quantification was performed based on external calibration with pure standards.

\section{Statistical analysis}

Analysis of variance and Tukey test were performed using Statgraphics (Statgraphics Technologies Inc).

\section{Results and discussion}

The fruit characteristics of the three genotypes evaluated are presented in Table 1. There was a significant difference for fruit weight, epicarp and endocarp contents (wet basis - WB), pulp moisture, pulp oil content (dry and wet basis) and pulp oil yield and total oil yield/fruit (WB) $(\mathrm{p}<0.05)$. The fruit weight varied from 29 to $38 \mathrm{~g}$ (fresh weight), which is consistent with the average result (39 g) reported by Vianna et al. (2017) and in the range of 24 to $58 \mathrm{~g}$ observed for 35 genotypes by Conceição et al. (2015b). The fruits showed epicarp and endocarp contents varying from 15 to $24 \%$ and 28 to $35 \%$ (WB), respectively, and both comprised around half of the fruit weight. The pulp and kernel contents (WB) varied around $41-44 \%$ and $6-8 \%$, respectively, and no difference was observed among the genotypes evaluated $(p>0.05)$. Although the pulp moisture $(50-63 \mathrm{~g} / 100 \mathrm{~g})$ was higher than kernel moisture (19-22 g/100g), the pulp oil content (7-29 g/100g WB or 19-60 g/100 g dry matter-DM) led to the pulp oil yield/fruit ranging from 3 to $12 \%$, showing a higher contribution to the total oil yield/fruit (6-15\%)(WB) than the kernel oil yield/fruit. The kernel oil content varied from 33-42 g/100g (DM) or 26-35 g/100g (WB). The Mac 3 genotype had the highest pulp oil content and total oil yield/fruit, while the Mac 2genotype presented the lowest figures among the evaluated genotypes. The parameters studied were in the range of those studied by Conceição et al. (2015b). It is noteworthy to highlight that Mac 3 presented the lowest fruit weight, but showed consistent pulp oil content (DM) with the most promising genotypes for oil source evaluated by Conceição et al. (2015b). 
Table 1. Fruit characteristics, oil content, oil yield and carotene in pulp oil of sweet macauba genotypes.

\begin{tabular}{lllll}
\hline \multirow{2}{*}{ Fruit characteristics } & \multicolumn{2}{l}{ Sweet macauba } & Macauba \\
\cline { 2 - 4 } & Mac 1 & Mac 2 & Mac 3 & Genotypes $^{1}$ \\
\hline Fruit weight (g) WB & $33.73^{\mathrm{ab}}$ & $37.66^{\mathrm{a}}$ & $29.10^{\mathrm{b}}$ & $24-58$ \\
Epicarp (\%) WB & $23.75^{\mathrm{a}}$ & $16.69^{\mathrm{b}}$ & $15.23^{\mathrm{b}}$ & $17-42$ \\
Mesocarp (\%) WB & $41.67^{\mathrm{a}}$ & $44.40^{\mathrm{a}}$ & $41.95^{\mathrm{a}}$ & $23-50$ \\
Kernel (\%) WB & $6.64^{\mathrm{a}}$ & $8.27^{\mathrm{a}}$ & $8.33^{\mathrm{a}}$ & $4-10$ \\
Epicarp + endocarp (\%) WB & $51.96^{\mathrm{a}}$ & $47.77^{\mathrm{a}}$ & $49.83^{\mathrm{a}}$ & - \\
Endocarp (\%) WB & $28.21^{\mathrm{b}}$ & $31.08^{\mathrm{ab}}$ & $34.61^{\mathrm{a}}$ & $19-34$ \\
Pulp oil (\%) DM & $39.91^{\mathrm{b}}$ & $18.96^{\mathrm{c}}$ & $60.25^{\mathrm{a}}$ & $15-77$ \\
Pulp moisture (\%) & $62.61^{\mathrm{a}}$ & $59.62^{\mathrm{a}}$ & $50.16^{\mathrm{b}}$ & \\
Pulp oil (\%) WB & $14.25^{\mathrm{b}}$ & $7.12^{\mathrm{c}}$ & $29.21^{\mathrm{a}}$ & \\
Kernel Moisture (\%) & $21.76^{\mathrm{a}}$ & $18.88^{\mathrm{a}}$ & $18.92^{\mathrm{a}}$ & \\
Kernel oil (\%) DM & $33.34^{\mathrm{a}}$ & $41.58^{\mathrm{a}}$ & $41.17^{\mathrm{a}}$ & $33-61$ \\
Kernel oil (\%) WB & $26.10^{\mathrm{a}}$ & $33.82^{\mathrm{a}}$ & $34.69^{\mathrm{a}}$ & \\
Pulp oil yield/fruit (\%) WB & $5.89^{\mathrm{b}}$ & $3.15^{\mathrm{c}}$ & $12.19^{\mathrm{a}}$ & \\
Kernel oil yield/fruit (\%) WB & $1.72^{\mathrm{a}}$ & $2.76^{\mathrm{a}}$ & $2.88^{\mathrm{a}}$ & \\
Total oil yield/fruit (\%) WB & $7.61^{\mathrm{b}}$ & $5.92^{\mathrm{b}}$ & $15.07^{\mathrm{a}}$ & $5-21$ \\
Carotenes of pulp oil (mg kg- ${ }^{1}$ ) & $102-240$ & 100 & $30-57$ & \\
\hline
\end{tabular}

Means followed by different lowercase letters in the same row are significantly different by the Tukey test $(\mathrm{p}<0.05)$.

${ }^{1}$ Conceição et al. (2015b)

WB - wet basis

$\mathrm{DM}$ - dry matter

The total sweet macauba mesocarp sugars ranged from 4.5 to $9.6 \mathrm{~g} / 100 \mathrm{~g}$ (WB) (Table 2). Sucrose was not detected, while the fructose results $(2.5$ to $5.3 \mathrm{~g} / 100 \mathrm{~g} \mathrm{WB}$ ) were higher than glucose ( 2 to $4.4 \mathrm{~g} / 100 \mathrm{~g} \mathrm{WB})$. Ramos et al. (2008) reported glucose $(9.47 \mathrm{~g} / 100 \mathrm{~g} \mathrm{WB})$ as the main monosaccharide of macauba mesocarp and fructose was not detected or no separation between these compounds was achieved, while sucrose was detected up to 0.07 $\mathrm{g} / 100 \mathrm{~g}$. The lower total sugars content was obtained for the Mac 3 sample which also showed the highest pulp oil content, while the highest total sugar content was observed for the Mac 2 sample, being the genotype with the lowest pulp oil content. Thus, the genetic diversity observed for the macauba genotypes for oil content may also be related to mesocarp composition. Knowledge regarding the sugar content is important when considering the sensory acceptance for possible products obtained from the pulp.

Table 2. Proximate composition of sweet macauba pulp (g/100g).

\begin{tabular}{lcccccc}
\hline \multirow{2}{*}{ Nutrient } & \multicolumn{6}{c}{ Sweet macauba genotypes } \\
& \multicolumn{2}{c}{ Mac 1} & \multicolumn{3}{c}{ Mac 2} & Mac 3 \\
\cline { 2 - 7 } & WB & DM & WB & DM & WB & DM \\
\hline Moisture $(\mathrm{g} / 100 \mathrm{~g})$ & 61.73 & - & 60.09 & - & 48.34 & - \\
Ash $(\mathrm{g} / 100 \mathrm{~g})$ & 1.79 & 4.7 & 2.02 & 5.1 & 2.01 & 3.9 \\
Lipids $(\mathrm{g} / 100 \mathrm{~g})$ & 15.28 & 39.9 & 7.57 & 19.0 & 24.89 & 48.2 \\
Protein $(\mathrm{g} / 100 \mathrm{~g})^{\mathrm{a}}$ & 1.67 & 4.4 & 1.72 & 4.3 & 2.24 & 4.3 \\
Total dietary fiber $(\mathrm{g} / 100 \mathrm{~g})$ & 9.27 & 24.2 & 6.84 & 17.1 & 8.69 & 16.8 \\
Total carbohydrates $(\mathrm{g} / 100 \mathrm{~g})^{\mathrm{b}}$ & 10.27 & 26.8 & 21.76 & 54.5 & 13.84 & 26.8 \\
Fructose $(\mathrm{g} / 100 \mathrm{~g})$ & 3.93 & 10.3 & 5.26 & 13.2 & 2.46 & 4.7 \\
Glucose $(\mathrm{g} / 100 \mathrm{~g})$ & 3.64 & 9.5 & 4.37 & 10.9 & 2.06 & 4.0 \\
Total sugars $(\mathrm{g} / 100 \mathrm{~g})$ & 7.57 & 19.8 & 9.63 & 24.1 & 4.51 & 8.7 \\
Calories $(\mathrm{kcal} / 100 \mathrm{~g})$ & 185 & - & 162 & - & 288 & - \\
\hline
\end{tabular}

\footnotetext{
${ }^{\text {a }}$ Protein content $=$ nitrogen $\times 5.75$

${ }^{\mathrm{b}}$ Total carbohydrates $=100-($ moisture + protein + lipids + total dietary fiber + ash $)$

WB - wet basis; DM- Dry basis
} 
The mesocarp showed total dietary fiber (TDF) varying from 6.8 to $9.3 \mathrm{~g} / 100$ (WB) (Table 2) or 17-24 $\mathrm{g} / 100 \mathrm{~g}(\mathrm{DM})$, being similar to the results $(17-23 \mathrm{~g} / 100 \mathrm{~g}$ DM) cited by Coimbra and Jorge (2011), TACO (2011) and Silva et al. (2008), however these authors did not include sugar determination data. In order to perform a comparison, the results should be calculated as dry basis, because the mesocarp moisture was different among genotypes, while the result for intake of the edible portion should be informed as wet basis. No other comparison was possible because the enzymatic gravimetric method for TDF analysis is expensive and time consuming. The Mac 2 and Mac 3 genotypes showed similar results, while Mac 1 presented the highest TDF content ( $24 \mathrm{~g} / 100 \mathrm{~g}$ DM).

The protein content of mesocarp varied from 1.7 to $2.2 \mathrm{~g} / 100 \mathrm{~g}$ (WB) and the results calculated as dry basis (4.3-4.4 g/100g) were similar to the range (3.2-4.2 g/100g DM) reported by Ramos et al. (2008), Silva et al. (2008) and TACO (2011), but lower than the result (6.7\% DM) cited by Coimbra and Jorge (2011). The ash contents $(1.8-2 \mathrm{~g} / 100 \mathrm{~g} \mathrm{WB}$ or $3.9-5.1 \mathrm{~g} / 100 \mathrm{~g} \mathrm{DM})$ were higher than the results obtained by Ramos et al. (2008), TACO (2011), Coimbra and Jorge (2011) and Silva et al. (2008), ranging from 2.1 to $3.2 \mathrm{~g} / 100 \mathrm{~g}(\mathrm{DM})$. The Mac 2 and Mac 3 genotypes presented the highest and the lowest ash contents, respectively. The variation in the mesocarp oil content (WB) between Tables 1 and 2 was related to sampling, as Table 1 presents the results for fruits which were evaluated separately, and Table 2 shows the sampling results of 10 fruits followed by homogenization. The results were in the range of pulp oil content obtained by Ramos et al. (2008) and TACO (2011), of 8 and 40 $\mathrm{g} / 100 \mathrm{~g}$ (WB), respectively. The carbohydrates calculated by difference varied from 10 to $22 \mathrm{~g} / 100 \mathrm{~g}$, and were only not consistent with sugar content. Further evaluation of the presence of starch as reported by Ramos et al. (2008) should be evaluated. The caloric value ranging from 162 to $288 \mathrm{kcal} / 100 \mathrm{~g}$ is mainly related to the high oil content.

The total dietary fiber (TDF), lipids, protein and ash contents of macauba pulp were higher than around 80 commercial and native fruits evaluated by the Brazilian composition table (TACO, 2011), except for pequi pulp (Caryocar spp.) and tucumã (Astrocaryum spp.) regarding TDF content and the protein content reported for tamarinds (Tamarindus indica).
The sweet macauba genotypes evaluated showed high total dietary fiber, sugars and oil contents presenting distinct patterns which can lead to different applications such as ice cream for samples with high oil content, and alcoholic liquors for samples with low oil content.

There were significant differences for fatty acids from mesocarp oil $(\mathrm{p}<0.05)$ (Table 3$)$, with the main fatty acids being C18:1 (36.4-62.5\%), C18:2 (7.5-35\%), C16:0 (15.9-22.8\%) and $\mathrm{C} 18: 3$ (0.8-7.1\%). The $\mathrm{C} 18: 1$ content was the sum of $\mathrm{C} 18: 1 \mathrm{cis}-9$ and $\mathrm{C} 18: 1 \mathrm{cis}-11$. A significant variation was also observed for $\mathrm{C} 16: 1(2.2-5 \%)$ and $\mathrm{C} 18: 0$ $(0.7-1.9 \%)(p<0.05)$ (Figure 1). The results obtained for Mac 1 and Mac 3 were in the range of Brazilian genotypes evaluated by Antoniassi et al. (2013). However, the Mac 2 sample presented a profile with higher linoleic acid - C18:2 (35\%) and lower $\mathrm{C} 18: 1$ content (36\%), while macauba mesocarp oil usually showed a high oleic acid profile (50-70\%)(ANTONIASSI et al., 2013). The high C18:1 content presented by Mac 1 and Mac 3 genotypes were in the range of olive oil (IOC, 2019). Moreover, the Mac 2 genotype presented the highest linolenic acid - C18:3 content (7.1\%) already found for Brazilian macauba genotypes (ANTONIASSI et al., 2013; HIANE et al., 2005; COIMBRA and JORGE, 2012), and for Costa Rica genotypes (LIEB at al., 2019) which showed linolenic acid content up to $2.6 \%$. The high linolenic acid observed was in the range reported for soybean and low erucic rapeseed oils (CXS 210, 1999), but which is uncommon in fruits (TACO, 2011). Linoleic acid (C18:2 n-6) and linolenic acid (C18:3n-3) are essential fatty acids that are required for good health (OTTEN et al., 2006), and the Mac 2 genotype can contribute to the daily intake of these fatty acids. Nevertheless, high oleic oils have been associated to a reduced risk of mortality and cardiovascular events (SCHWINGSHACKL and HOFFMANN, 2014; HUTH et.al, 2015). Thus the variability observed for sweet macauba genotypes are interesting from a nutritional point of view. Additionally, the sum of monounsaturated (39$68 \%)$ and polyunsaturated fatty acids $(8-42 \%)$ led to the large iodine value range of $74-113 \mathrm{~g} / 100 \mathrm{~g}$, characteristic to oilseeds cultivars showing high oleic or high linoleic sunflower seed oils (for example), while the saponification value varied from 195 to $197 \mathrm{mg} \mathrm{KOH} / \mathrm{g}$ as the result of the fatty acid profile from C16:0 to C18:3 fatty acids (CXS 210, 1999). 


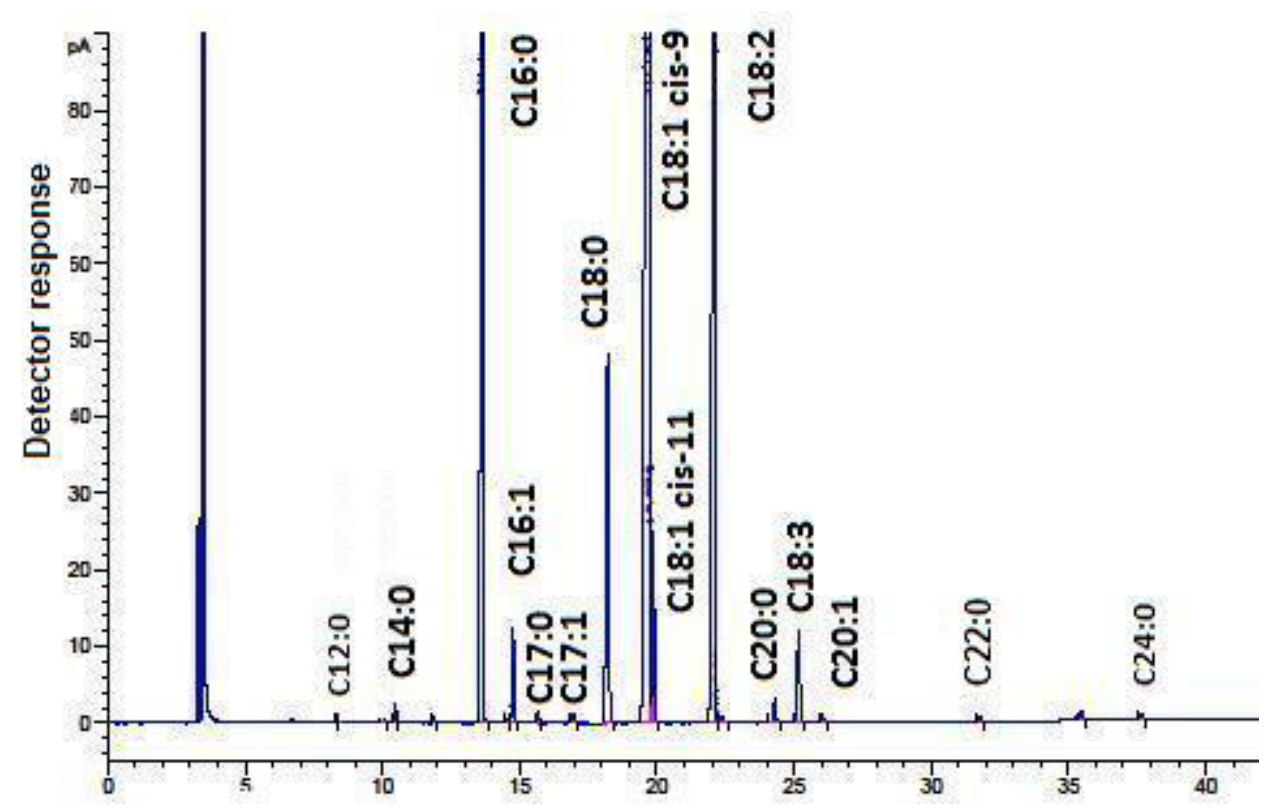

Figure 1. Chromatogram of fatty acid methyl esters of macauba mesocarp oil.

Table 3. Fatty acid profile of pulp oil (g fatty acid/total fatty acids) of sweet macauba genotypes.

\begin{tabular}{|c|c|c|c|c|}
\hline \multirow{2}{*}{ Fatty acid } & \multicolumn{3}{|c|}{ Sweet macauba } & \multirow{2}{*}{-Macauba genotypes } \\
\hline & Mac 1 & Mac 2 & Mac 3 & \\
\hline $\mathrm{C} 14: 0$ & 0.4 & 0.6 & 0.1 & $0.03-0.18$ \\
\hline $\mathrm{C} 15: 0$ & 0.05 & 0.06 & $\mathrm{nq}$ & \\
\hline $\mathrm{C} 16: 0$ & $22.1^{\mathrm{a}}$ & $15.9^{b}$ & $22.8^{a}$ & $10.1-25.3$ \\
\hline $\mathrm{C} 16: 1$ & $2.4^{\mathrm{b}}$ & $2.2^{\mathrm{b}}$ & $5.0^{\mathrm{a}}$ & $0.6-6.9$ \\
\hline $\mathrm{C} 17: 0$ & 0.07 & 0.06 & $\mathrm{nq}$ & \\
\hline $\mathrm{C} 17: 1$ & 0.1 & 0.06 & $0-0.1$ & \\
\hline C18:0 & $1.9^{\mathrm{a}}$ & $0.7^{\mathrm{c}}$ & $1.1^{\mathrm{b}}$ & $0.5-5.5$ \\
\hline C18:1 & $58.1^{\mathrm{b}}$ & $36.4^{\mathrm{c}}$ & $62.5^{\mathrm{a}}$ & $50-70$ \\
\hline C18:2 & $12.4^{b}$ & $35.0^{\mathrm{a}}$ & $7.5^{\mathrm{c}}$ & $7.2-20$ \\
\hline $\mathrm{C} 20: 0$ & 0.2 & 0.2 & $0-0.1$ & $0-0.2$ \\
\hline $\mathrm{C} 18: 3$ & $1.6^{\mathrm{b}}$ & $7.1^{\mathrm{a}}$ & $0.8^{\mathrm{c}}$ & $0.8-2.1$ \\
\hline C20:1 & $0-0.3$ & 0.3 & $\mathrm{nq}$ & $0.02-0.22$ \\
\hline $\mathrm{C} 22: 0$ & $\mathrm{nq}$ & $0-0.2$ & $\mathrm{nq}$ & \\
\hline $\mathrm{C} 24: 0$ & $0-0.06$ & 0.1 & $\mathrm{nq}$ & \\
\hline$\sum$ Saturated & 24.7 & 17.9 & 24.1 & \\
\hline$\Sigma$ Monounsaturated & 60.8 & 38.9 & 67.6 & \\
\hline$\Sigma$ Polyunsaturated & 13.9 & 42.1 & 8.3 & \\
\hline IS & 196 & 197 & 195 & \\
\hline II & 78 & 113 & 74 & \\
\hline
\end{tabular}

followed by different lowercase letters in the same row are significantly different by the Tukey test $(\mathrm{p}<0.05)$.

$\mathrm{Nq}$ - not quantified

Saturated-Saturated fatty acids $(\mathrm{C} 14: 0+\mathrm{C} 15: 0+\mathrm{C} 16: 0+\mathrm{C} 17: 0+\mathrm{C} 18: 0+\mathrm{C} 20: 0+\mathrm{C} 22: 0+\mathrm{C} 24: 0)$

Monounsaturated - Monounsaturated fatty acids $(\mathrm{C} 16: 1+\mathrm{C} 17: 1+\mathrm{C} 18: 1+\mathrm{C} 20: 1)$

Polyunsaturated - Polyunsaturated fatty acids $(\mathrm{C} 18: 2+\mathrm{C} 18: 3)$

II - Iodine value $\left({\left.\mathrm{g} 100 \mathrm{~g}^{-1}\right)}^{-1}\right.$

IS - Saponification value $\left(\mathrm{mg} \mathrm{KOH} \mathrm{g}^{-1}\right)$

${ }^{1}$ Antoniassi et al. (2013) 
No difference was observed among genotypes regarding the fatty acid composition of the kernel oil $(\mathrm{p}<0.05)($ Table 4$)$. The main fatty acids were lauric $\mathrm{C} 12: 0(37-38 \%)$ and $\mathrm{C} 18: 1$ (27-29\%), in addition to C8:0, C10:0 and C14:0, showing a profile of lauric oils (Figure 2). Although the results for the sweet macauba genotypes were in the range observed for other Brazilian A. aculeata genotypes (ANTONIASSI et al., 2013), the C18:1 concentration was higher than that observed for the commercial lauric oils such as coconut, palm kernel and babassu oils (CXS 210, 1999), as well as other kernel oils from the Arecaceae family such as Astrocaryum vulgare (BORA et al., 2001) and Astrocaryum aculeatum (DIDONET et al., 2020), ranging from 5-21\%. Thus, the sum of unsaturated fatty acids (30-33\%) and the iodine value $(30-32 \mathrm{~g} / 100 \mathrm{~g})$ were higher and the sum of saturated fatty acids (67-69\%) and Saponification value (227-230 $\mathrm{mg} \mathrm{KOH} / \mathrm{g}$ ) were lower than the commercial lauric oils (CXS 210, 1999).

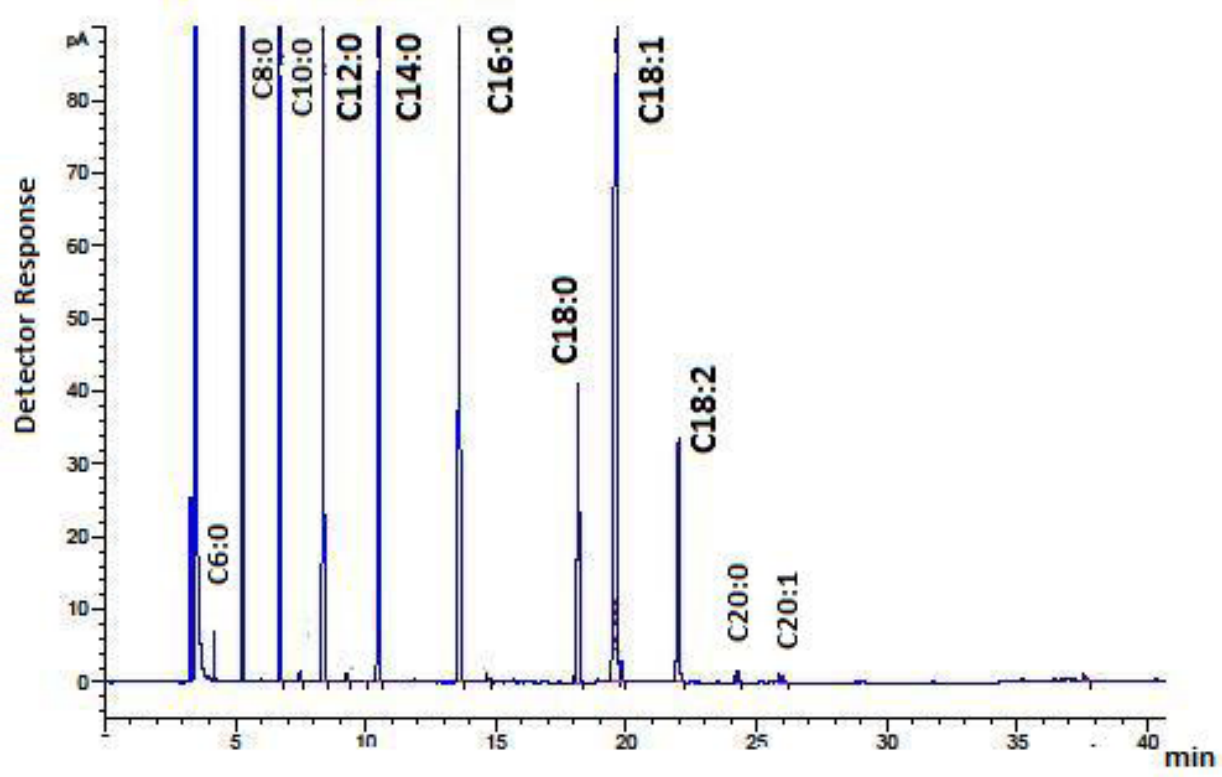

Figure 2. Chromatogram of fatty acid methyl esters of macauba kernel oil.

Table 4. Fatty acid profile of kernel oil (g fatty acid/ total fatty acids) from fruits of sweet macauba genotypes.

\begin{tabular}{lllll}
\hline \multirow{2}{*}{ Fatty acid } & \multicolumn{3}{l}{ Sweet macauba } & \multirow{2}{*}{ Macauba genotypes ${ }^{1}$} \\
\cline { 2 - 5 } & Mac 1 & Mac 2 & Mac 3 & \\
\hline C8:0 & $3.7^{\mathrm{a}}$ & $3.9^{\mathrm{a}}$ & $5.1^{\mathrm{a}}$ & $3.1-6.2$ \\
$\mathrm{C} 10: 0$ & $4.0^{\mathrm{a}}$ & $3.8^{\mathrm{a}}$ & $4.2^{\mathrm{a}}$ & $2.6-5.9$ \\
$\mathrm{C} 12: 0$ & $37.8^{\mathrm{a}}$ & $38.6^{\mathrm{a}}$ & $37.4^{\mathrm{a}}$ & $31-47$ \\
$\mathrm{C} 14: 0$ & $9.8^{\mathrm{a}}$ & $10.1^{\mathrm{a}}$ & $10.5^{\mathrm{a}}$ & $9-12$ \\
$\mathrm{C} 16: 0$ & $8.4^{\mathrm{a}}$ & $8.4^{\mathrm{a}}$ & $8.7^{\mathrm{a}}$ & $5.8-11$ \\
$\mathrm{C} 16: 1$ & $0-0.06$ & 0.05 & 0.06 & \\
$\mathrm{C} 18: 0$ & $3.0^{\mathrm{a}}$ & $3.6^{\mathrm{a}}$ & $3.1^{\mathrm{a}}$ & $2.8-4.5$ \\
$\mathrm{C} 18: 1$ & $29.3^{\mathrm{a}}$ & $27.3^{\mathrm{a}}$ & $26.8^{\mathrm{a}}$ & $19.8-32$ \\
$\mathrm{C} 18: 2$ & $3.6^{\mathrm{a}}$ & $3.8^{\mathrm{a}}$ & $3.7^{\mathrm{a}}$ & $2.7-4.6$ \\
$\mathrm{C} 20: 0$ & $0-0.1$ & 0.15 & $0-0.1$ & $0.05-0.18$ \\
C20:1 & $0-0.14$ & $0-0.1$ & $\mathrm{nq}$ & \\
C24:0 & $0-0.04$ & $0-0.06$ & $\mathrm{nq}$ & \\
\hline$\Sigma$ Saturated & 66.9 & 68.6 & 69.1 & \\
$\Sigma$ Unsaturated & 33.1 & 31.2 & 30.6 & \\
II & 32 & 30 & 30 & \\
IS & 227 & 228 & 230 & \\
\hline
\end{tabular}

Means followed by different lowercase letters in the same row are significantly different by the Tukey test $(\mathrm{p}<0.05)$.

nq - not quantified

Saturated - saturated fatty acids $(\mathrm{C} 8: 0+\mathrm{C} 10: 0+\mathrm{C} 12: 0+\mathrm{C} 14: 0+\mathrm{C} 16: 0+\mathrm{C} 18: 0+\mathrm{C} 20: 0+\mathrm{C} 24: 0)$

Unsaturated - unsaturated fatty acids $(\mathrm{C} 16: 1+\mathrm{C} 18: 1+\mathrm{C} 18: 2+\mathrm{C} 20: 1)$

II - Iodine value $(\mathrm{g} / 100 \mathrm{~g})$

IS - Saponification value $(\mathrm{mg} \mathrm{KOH} / \mathrm{g})$

${ }^{1}$ Antoniassi et al. (2013) 
The carotene content of mesocarp oil varied from 30 to $240 \mathrm{mg} / \mathrm{kg}$, showing large variation among the evaluated fruits; Mac 3 showed the lowest figures, while Mac 1 presented the highest carotene content (Table 1). Ramos et al. (2008) reported total carotene content in fresh $A$. aculeata pulp of $49 \mu \mathrm{g} / \mathrm{g}$ and $\beta$-carotene as the main component. Rodriguez-Amaya et al. (2017) reported buriti (Maximiliana vinifera), macauba and tucuma (Astrocaryum vulgare) fruits as the main sources of $\beta$-carotene, which is the precursor of vitamin $A$, and therefore could be used to prevent vitamin A deficiency.

The differences in nutritional value observed for the sweet macauba genotypes were attributed to genetic diversity because these fruits were collected at the same ripening stage and these genotypes were grown in similar conditions in the Cerrado region. Ripe fruits detached from the bunches and they were collected using some nets in order to avoid fruit damage.

The genetic diversity related to fruit characteristics, oil content and fatty acid profile was also observed by Conceição et al. (2013a, 2013b, 2015b) for A. aculeata genotypes from Brazil. The impact of the genotypes variation was also observed by Górnaś et al. $(2017,2018)$ for fatty acids of kernel oil among plum (Prunus domestica L. and $P$. cerasifera) and apricot ( $P$. armeniaca) genotypes.

The Mac 2 genotype had a different nutritional composition among the sweet macauba genotypes as well as for other macauba genotypes evaluated in Brazil, presenting the highest linoleic and linolenic acid, total sugars and ash contents, and the lowest oil content for the pulp. Additionally, the Mac 3 genotype showed the highest pulp oil content and the lowest total sugars content, while Mac 1 displayed intermediate total sugars and oil contents and presented the highest TDF content.

The nutritional composition of fruits provides valuable information considering health benefits and possible effects on the sensory characteristics of the products from the macauba mesocarp.

\section{Conclusion}

The variation observed among sweet macauba genotypes mainly related to the fatty acids of mesocarp oil, mesocarp oil content and nutritional value was attributed to genetic diversity among genotypes.

The pulp oil of two selected genotypes presented fatty acid profile of high oleic acid and low linoleic and linoleic acid contents, but one genotype showed a distinct fatty acid profile with high linoleic and linolenic acid contents.

The mesocarp showed high total dietary fiber, oil content, protein and ash contents among the highest results observed for commercial and native fruits from Brazil.

\section{Acknowledgements}

This work was supported by Finep (Financiadora de Estudos e Projetos), CNPq (Conselho Nacional de Desenvolvimento Científico e Tecnológico) and Petrobrás.

\section{References}

ALMEIDA, S.D. Cerrado: aproveitamento alimentar. Planaltina: Embrapa-CPAC, 1998.

ANTONIASSI, R.; CONCEIÇÃO, L.D.H.C.S.; JUNQUEIRA, N.T.V.; BRAGA, M.F.; FARIAMACHADO, A.F.; SANTOS, M.C.S.; BIZZO, H.R. Ácidos graxos em frutos de macaúbas. In: CONGRESSO BRASILEIRO DE MACAÚBA, 1., 2013, Patos de Minas. Anais [...]. Brasília, DF: MAPA, 2013.

AOAC- Association of Official Analytical Chemists. Official method of analysis. $18^{\text {th }} \mathrm{ed}$. Washington, 2005.

BERGMANN, J.C.; TUPINAMBÁ, D.D.; COSTA, O.Y.A.; ALMEIDA, J.R.M.; BARRETO, C.C.; QUIRINO, B.F. Biodiesel production in Brazil and alternative biomass feedstocks. Renewable and Sustainable Energy Reviews, Oxford, v.21, p.411-420, 2013.

BORA, P.S.; NARAIN, N.; ROCHA, R.V.M.; OLIVEIRA MONTEIRO, A.C.; AZEVEDO MOREIRA, R. Characterization of the oil and protein fractions of tucuma (Astrocaryum vulgare Mart.) fruit pulp and seed kernel (Astrocaryum vulgare Mart.). CYTA-Journal of Food, Abingdon, v.3, p.111-116, 2001.

BRASIL. Resolução RDC no 360 , de 23 de dezembro de 2003. Aprova regulamento técnico sobre rotulagem nutricional de alimentos embalados, tornando obrigatória a rotulagem nutricional. Diário Oficial [da] República Federativa do Brasil, Seção 1, n.251, p.33, 23 dez. 2003.

COIMBRA, M.C.; JORGE, N. Fatty acids and bioactive compounds of the pulps and kernels of Brazilian palm species, guariroba (Syagrus oleraces), jerivá (Syagrus romanzoffiana) and macaúba (Acrocomia aculeata). Journal of the Science of Food and Agriculture, New York, v.92, p.679-684, 2012.

COIMBRA, M.C.; JORGE, N. Proximate composition of guariroba (Syagrus oleracea), jerivá (Syagrus romanzoffiana) and macaúba (Acrocomia aculeata) palm fruits. Food Research International, New York, v.44, n. 7, p.2139-2142, 2011. 
COLOMBO, C.A.; BERTON, L.H.C.; DIAZ, B.G.; FERRARI, R.A. Macauba: a promising tropical palm for the production of vegetable oil. OCL, Montrouge, v.25, n.1, p.108, 2018.

CONCEIÇÃO, L.D.H.C.S.; ANTONIASSI, R.; JUNQUEIRA, N.T.V.; BRAGA, M.F.; FARIAMACHADO, A.F.; ROGÉRIO, J.B.; DUARTE, I.D.; BIZZO, H.R. Genetic diversity of macauba from natural populations of Brazil. BMC Research Notes, London, v.8, p.406, 2015b.

CONCEIÇÃO, L.D.H.C.S.; JUNQUEIRA, N.T.V.; MOTOIKE, S.Y.; PIMENTEL, L.D.; FAVARO, S.P.; BRAGA, M.F.; ANTONIASSI, R. Macaúba. In: LOPES, R.; OLIVEIRA, M.S.P.; CAVALLARI, M.M.; BARBIERI, R.L.; CONCEIÇÃO, L.H.C.S.C. (ed.). Palmeiras nativas do Brasil. Brasília (DF): Embrapa, 2015a. p.269-305.

CONCEIÇÃO, L.D.H.C.S.; ANTONIASSI, R.; JUNQUEIRA, N.T.V; BRAGA, M.F.; FARIAMACHADO, A.F.; ROGÉRIO, J.B.; BIZZO, H.R.; CASTRO, P.R. Divergência em macaúba baseada em análises de ácidos graxos. In: CONGRESSO BRASILEIRO DE MACAÚBA, 1., 2013, Anais [...]. Brasília, DF: MAPA, 2013a.

CONCEIÇÃO, L.D.; ANTONIASSI, R.; JUNQUEIRA, N.T.V.; BRAGA, M.; LICURGO, F.M.D.S.; DUPRAT, I.D.; CASTRO, P.R.(2013).Divergência genética baseada em avaliações físico-oleíferos em frutos de macaúba. In: CONGRESSO BRASILEIRO DE MACAÚBA, 1., 2013, Anais [...]. Brasília, DF: MAPA, $2013 b$.

CXS 210-1999. Standard for named vegetable oils. Codex Alimentarius. International Food Standards, 2019. Disponível em: http://www.fao.org/fao-whocodexalimentarius/codex-texts/list-standards/en/.

DAVIES, B.H. Carotenoids. In: GOODWIN, T.W. (ed.) Chemistry and biochemistry of plant pigments. $2^{\text {nd }} \mathrm{ed}$. London: Academic Press, 1976. v.2, p 38-165.

DIDONET, A.A.; ANTONIASSI, R.; BACK, G.R.; FARIA MACHADO, A.F.; WILHELM, A.E.; FERRAZ, I.D.K. Characterization of amount and quality of tucuman kernel oil as a potential biomass. Journal of the American Oil Chemists' Society, v.97, 955-962, 2020. Disponível em: https://aocs.onlinelibrary.wiley.com/doi/abs/10.1002/ aocs.12374.

FERRARI, R.A.; AZEVEDO FILHO, J.A. Macauba as promising substrate for crude oil and biodiesel production. Journal of Agricultural Science and Technology B, Tehran, v.2, n.10B, p.1119, 2012.
GÓRNAŚ, P.; RUDZIŃSKA, M.; SOLIVEN, A. Industrial by-products of plum Prunus domestica L. and Prunus cerasifera Ehrh. as potential biodiesel feedstock: impact of variety. Industrial Crops and Products, Amsterdam, v.100, p.77-84, 2017.

GÓRNAŚ, P.; RAMOS, M.J.; MONTANO, M.C.; RUDZIŃSKA, M.; RADZIEJEWSKA KUBZDELA, E., GRYGIER, A. Fruit pits recovered from 14 genotypes of apricot (Prunus armeniaca L.) as potential biodiesel feedstock. European Journal of Lipid Science and Technology, Weinheim, v.120, n.2, p.1700147, 2018.

HARTMAN, L.; LAGO, R.C.A. Rapid Preparation of fatty acid methyl esters from lipids. Laboratory Practice, London, v.22, p.475-476, 1973.

HIANE, P.A.; RAMOS FILHO, M.M.; RAMOS, M.I.L.; MACEDO, M.L.R. Óleo da polpa e amêndoa de bocaiúva, Acrocomia aculeata (jacq.) lodd. Caracterização e composição em ácido graxos. Brazilian Journal of Food Technology, Campinas, v.8, p.256-259, 2005.

HUTH, P.J.; FULGONI III, V.L.; LARSON, B.T. A systematic review of high-oleic vegetable oil substitutions for other fats and oils on cardiovascular disease risk factors: implications for novel high-oleic soybean oils. Advances in Nutrition, Bethesda, v.6, p.674-693, 2015.

IOC - International Olive Council. Trade standard applying to olive oils and olive pomace oils. 2019. (COI/T.15/ NC No 3/ REV.14). Disponível em: https://www.internationaloliveoil.org/wp-content/ uploads/2019/12/trade-standard-rev-14-eng.pdf

LESCANO, C.H.; OLIVEIRA, I.P.; SILVA, L.R.; BALDIVIA, D.S.; SANJINEZ-ARGANDOÑA, E.J.; ARRUDA, E.J.; LIMA, F.F. Nutrients content, characterization and oil extraction from Acrocomia aculeata (Jacq.) Lodd. fruits. African Journal of Food Science, Brooklyn, v.9, p.113-119, 2015.

LIEB, V.M.; SCHEX, R.; ESQUIVEL, P.; JIMÉNEZ, V.M.; SCHMARR, H.G.; CARLE, R.; STEINGASS, C.B. Fatty acids and triacylglycerols in the mesocarp and kernel oils of maturing Costa Rican Acrocomia aculeata . NFS Journal, Amsterdam, v.14, p.6-13, 2019.

LOPES, D.C.; STEIDLE NETO, A.J. Potential crops for biodiesel production in Brazil: a review. World Journal of Agricultural Sciences, Albany, v.7, p.206-217, 2011.

LORENZI, G.M.A.C.; NEGRELLE, R.R.B. Acrocomia aculeata (JACQ.) Lodd.Ex Mart.: aspectos ecológicos. Usos e potencialidades. Visão Acadêmica, Curitiba, v.7, p.1, 2006. 
LORENZI, H.; NOBLICK, L.; KAHN, F.; FERREIRA, E. Flora brasileira: Arecaceae (Palmeiras). Nova Odessa: Instituto Plantarum, 2010. 384p.

MOOZ, E.D.; CASTELUCCI, A.C.L.; SPOTO, M.H.F. Potencial tecnológico e alimentício de frutos de macaúba Acrocomia aculeata (Jacq.) Lodd. Revista Brasileira de Pesquisa de Alimentos, Campo Mourão, v.3, p.86-89, 2012.

OTTEN, J.J.; MEYERS, L.D.; HELLWIG, J.P. (ed.). Dietary reference intakes: the essential guide to nutrient requirements. Washington: Institute of Medicine, National Academies Press, 2006.

RAMOS, M.I.L.; RAMOS FILHO, M.M.; HIANE, P.A.; BRAGA NETO, J.A.; SIQUEIRA, E.M.D.A. Qualidade nutricional da polpa de bocaiúva Acrocomia aculeata (Jacq.) Lodd. Food Science and Technology, London, v.28, p.90-94, 2008.

RODRIGUEZ-AMAYA, D.B.; KIMURA, M.; AMAYAFARFAN, J. Fontes brasileiras de carotenóides: tabela brasileira de composição de carotenóides em alimentos. Brasília (DF): Ministério de Meio Ambiente (MMA), 2017. Disponível em: https:/www.mma.gov.br/estruturas/ sbf agrobio/_publicacao/89 publicacao09032009113306. pdf.

SCARIOT, A.; LLERAS, E.; HAY, J.D. Flowering and fruiting phenologies of the palm Acrocomia aculeata: patterns and consequences. Biotropica, Hoboken, v.27, n.2, p.168-173, 1995.
SCHWINGSHACKL，L.; HOFFMANN，G. Monounsaturated fatty acids, olive oil and health status: a systematic review and meta-analysis of cohort studies. Lipids in Health and Disease, Dordrecht, v.13, n.1, p. 154, 2014.

SILVA, M.R.; CAVALCANTE LEMOS LACERDA, D.B.; SANTOS, G.G.; OLIVEIRA MARTINS, D.M. Chemical characterization of native species of fruits from savanna ecosystem. Ciência Rural, Santa Maria, v.38, n.6, p.1790-1793, 2008.

TACO. Tabela brasileira de composição de alimentos. 4.ed. Campinas: NEPA/ UNICAMP, 2011. 161 p. Disponível em: https://www.cfn.org.br/wp-content/ uploads $/ 2017 / 03 /$ taco_ 4 edicao_ampliada_e_revisada. pdf.

VIANNA, S.A.; BERTON, L.H.C.; POTT, A.; GUERREIRO, S.M.C.; COLOMBO, C.A. Biometric characterization of fruits and morphoanatomy of the mesocarp of Acrocomia species (Arecaceae). International Journal of Biology, Ontário, v.9, p.7892, 2017. 